\title{
Financial Distress in Indian Aviation Industry: Investigation Using Bankruptcy Prediction Models
}

\author{
Samik SHOME*, Sushma VERMA**
}

Received: March 26, 2020

Revised: May 12, 2020

Accepted: May 20, 2020.

\begin{abstract}
The Indian aviation sector over the recent years has shown a significant growth prospects on various parameters like passenger traffic, freight traffic, aircraft movements and number of airports, among others. But ironically the financial performance of most of the air carrier individually is not at all impressive. Every five years one airline in India is being grounded, latest being Jet Airways which had to suspend its operations in April 2019 due to severe financial crunch. The primary aim of this paper is to assess the current financial health of different Indian airline companies. This study uses four different models i.e. Altman Modified Z" Score Model, Pilarski Model, Fuzzy Logic Model and Kroeze Model to test the existence of financial distress and simultaneously aims to assess the applicability of these models on the Indian aviation sector. The models have been applied on four airline companies. Models indicate the existence of severe financial distress in three out of four chosen airlines and also indicate their suitability to be applied to the sector. The study contributes to the existing literature on Indian aviation by attempting to indicate the suitability of studied models for indicating financial distress which can lead to potential bankruptcy.
\end{abstract}

Keywords: Financial Distress, Bankruptcy, Indian Aviation Sector, Financial Ratios, Financial Models

JEL Code Classification: G32, G33, G38

UDC: 336.63

DOI: https://doi.org/10.17015/ejbe.2020.025.06

\footnotetext{
* Corresponding Author, Institute of Management, Nirma University at Ahmedabad, India. Email: samik@nirmauni.ac.in

**VES Institute of Management Studies and Research at Mumbai, India. Email: sushma.verma@ves.ac.in 


\section{Introduction}

Air transportation has become a significant industry over time and it plays a key role in global tourism and supply chain functions. This industry generates substantial employment and contributes majorly to global economic growth (Fung, Law \& Ng, 2006). However, it is also susceptible to several intrinsic and extraneous risks. These risks include economic boom and bust cycles, volatility in oil prices and exchange rates, infrastructure challenges, protectionism, wars and political upheavals, among others. This industry is also vulnerable to various other events such as weather conditions, terrorist attack as well as natural disasters ${ }^{1}$. All these issues lead to significant fluctuations in the profitability of air carrier or airline, the words used interchangeably in the paper.

In any free market economy, the competition will increase between the parties involved. The hallmark of this economic system is that some firms will inevitably fail. The more efficient firms will succeed, and the poorly managed will fail, allowing others to take their place. Thus, cost efficiency is of great importance (Lukic, 2014). According to economic theory, an existing airline will be able to succeed as long as it is operated and managed efficiently; if it fails, a more efficient airline will replace it. Hence, it is extremely important to have an early warning signal of financial distress in such a scenario. Warren Buffett once referred the aviation industry as the death trap for investors ${ }^{2}$.

The Indian aviation sector which is highly competitive in nature has shown considerable growth prospects especially in the domestic segment in the past few years. India is the third largest domestic civil aviation market in the world and is expected to move to become third largest air passenger market by $2024^{3}$. As the airline industry in India operates in a tight competition, the ability of different airline companies to increase prices is restricted to a great extent. More often prices are even slashed to attract the customers. But for maximizing profit, revenue maximization is also as necessary as minimizing cost (Jayaraman \& Srinivasan, 2014). Since profitability is considered to be critical for growth and survival of any industry (Tyagi \& Nauriyal, 2016), the companies belonging to the aviation sector have to pursue new strategies to maintain profit margins. In such a dynamic scenario, there is a very high propensity for financial distress for these companies which eventually lead to financial bankruptcies.

Several instances of financial distress have been observed among airline companies in India within the last decade. For example, Kingfisher airlines had to stop its operation in 2012 due to their inability to pay for its liabilities. Spice Jet cancelled

\footnotetext{
1 Airlines for America (A4A), Airline Handbook, Available at: http://airlines.org/Pages/AirlineHandbookChapter-1-Brief-History-of-Aviation.aspx, accessed on June 22, 2019.

2 https://www.forbes.com/sites/tedreed/2013/05/13/buffett-decries-airline-investing-even-though-atworst-he-broke-even/\#51554ecb3b5e, accessed on June 27, 2019.

${ }^{3}$ https://www.ibef.org/industry/indian-aviation.aspx. Accessed on February 28, 2020.
} 
more than 2000 flights at the end of 2014 due to huge accumulated losses. It was bailed out only by additional funding from promoters. Similarly, in 2016, Air Asia had to put its expansion plan on hold due to a severe cash crunch. Air Pegasus became bankrupt in 2017. In the same year, Air Carnival and Air Costa had to close down their operation. In recent times, in 2019, Jet Airways operations are completely suspended due to financial crunch. This sequence of financial distress and bankruptcies of several air carriers in India has led to an interest to study the probability of others becoming bankrupt in the near future. This prediction of bankruptcy is considered to be very significant in providing valuable insight to various stakeholders including customers.

According to Altman (1983), financial distress can be predicted before its occurrence (maybe even up to three years) using financial ratios with appropriate statistical analysis. If it can be accurately calculated to predict failures well in time, there is always a possibility to take corrective measures to reverse the phenomenon. In this backdrop, the primary aim of this paper is to investigate the current financial health of different Indian airline companies. An in-depth analysis of the same will be done using different models available including both generic and aviation industryspecific. The study also wishes to assess the applicability of these models in the Indian scenario. The study contributes to the existing literature on Indian aviation by attempting to indicate the suitability of studied models for indicating financial distress which can lead to potential bankruptcy.

The organization of the paper is as follows. A snapshot of the Indian aviation industry has been provided in Section 2. Next, in Section 3, a brief review of the literature is undertaken. The research methodology used in the paper is discussed in Section 4. The research findings and discussions are presented in Section 5 , followed by certain concluding remarks in Section 6.

\section{Indian Aviation Industry: A Snapshot}

The aviation industry in India has observed a rising splurge post 2012. India became the fastest growing aviation market followed by China. According to the Director General of Civil Aviation (DGCA) ${ }^{4}$, there was a growth of 18.1 per cent in overall passenger traffic (domestic plus international) leading to a total of 147.1 million passengers in $2017-18^{5}$ as compared to the previous year (Table 1). In the same period, the growth rate in domestic traffic was 18.9 per cent totalling to 123.3 million travellers and in international traffic, it was 14.4 per cent totalling to 23.8 million travellers. It can be noted that the number of passengers flown within and outside the country has increased by more than double in the past seven years. DGCA predicts that this number of air passengers would increase by almost 3.3 times in the

\footnotetext{
${ }^{4}$ DGCA is the regulatory body for civil aviation in India under the Ministry of Civil Aviation.

${ }^{5}$ 2017-18 implies financial year. Indian Financial Year (FY) is from 1st April to succeeding 31st March.
} 
next 20 years making it approximately 500 million passenger journeys per annum ${ }^{6}$. The year 2012-13 showed a negative growth both in terms of domestic as well as international passengers probably due to grounding of Kingfisher airlines during that time and relatively higher fare.

\section{Table 1. Domestic and International Passenger Traffic in India}

\begin{tabular}{lccccccc}
\hline Year & $\begin{array}{c}\text { Scheduled } \\
\text { Domestic } \\
\text { passengers } \\
\text { (in million) }\end{array}$ & $\begin{array}{c}\text { Scheduled } \\
\text { International } \\
\text { passengers } \\
\text { (in million) }\end{array}$ & $\begin{array}{c}\text { Yearly } \\
\text { growth in } \\
\text { domestic } \\
\text { passengers }\end{array}$ & $\begin{array}{c}\text { CAGR } \\
\text { domestic } \\
\text { passengers }\end{array}$ & $\begin{array}{c}\text { Yearly growth } \\
\text { in } \\
\text { international } \\
\text { passengers }\end{array}$ & $\begin{array}{c}\text { Yearly } \\
\text { CAGR } \\
\text { Passengers }\end{array}$ & $\begin{array}{c}\text { Yowth in } \\
\text { grownal } \\
\text { total }\end{array}$ \\
\hline $2010-11$ & 53.84 & 13.16 & 18.8 & 6.7 & 13.3 & 13 & 17.7 \\
$2011-12$ & 60.84 & 14.38 & 13.0 & 8.2 & 9.3 & 12.1 & 12.3 \\
$2012-13$ & 57.87 & 13.73 & $(4.9)$ & 5.4 & $(4.5)$ & 8.5 & $(4.8)$ \\
$2013-14$ & 60.67 & 15.77 & 4.8 & 5.3 & 14.8 & 9.6 & 6.8 \\
$2014-15$ & 70.08 & 17.33 & 15.5 & 6.7 & 9.9 & 9.6 & 14.4 \\
$2015-16$ & 85.20 & 18.63 & 21.6 & 8.5 & 7.5 & 9.4 & 18.8 \\
$2016-17$ & 103.75 & 20.81 & 21.8 & 9.9 & 11.8 & 9.6 & 20.0 \\
$2017-18$ & 123.32 & 23.80 & 18.9 & 10.8 & 14.4 & 10.1 & 18.1 \\
\hline
\end{tabular}

Source: http://dgca.gov.in/reports/stat-ind.htm

Note: Figures in parentheses implies negative numbers

The growth in air passenger traffic was only 3.7 per cent in 2019 , showing a steep fall from the growth rate of 18-19 per cent of the previous year. This is due to various reasons, prima facie being grounding of Jet Airways and a subdued economy. However, there is a very significant growth potential of this sector in India. There are several factors that may contribute to this growth: (a) decrease in the cost of air travel; (b) growth in the population of the middle-income group; and (c) inadequate capacity of other travel alternatives like, railways ${ }^{7}$.

Another important aspect in the airline industry is the significant use of leased aircraft. Data from Center for Asia Pacific Aviation (CAPA) fleet database exhibits that out of 652 commercially operated aircraft (including that in storage) in India as on October 17, 2018, approximately 81 per cent are leased ${ }^{8}$ (Figure 1). This is much higher as compared to 53 per cent of leased aircraft share globally and approximately 52 per cent in Asia. Indigo with 144 leased aircraft and Jet Airways with 106 leased aircraft together accounts for 47 per cent of the total leased aircraft in India followed by Air India ( 87 aircraft) and Spice Jet (58 aircraft).

\footnotetext{
6 https://www.iata.org/publications/economics/Reports/India-aviaion-summit-Aug18.pdf accessed on July 7, 2019.

7 http://www.careratings.com/upload/NewsFiles/Studies/Airlines\%20and\%20Airports.pdf accessed on July 7, 2019.

8https://centreforaviation.com/analysis/reports/aircraft-leasing-in-india-opportunity-knocks-for-anindian-lessor -443995, accessed on June 8, 2019.
} 
Financial Distress in Indian Aviation Industry: Investigation Using Bankruptcy Prediction ...

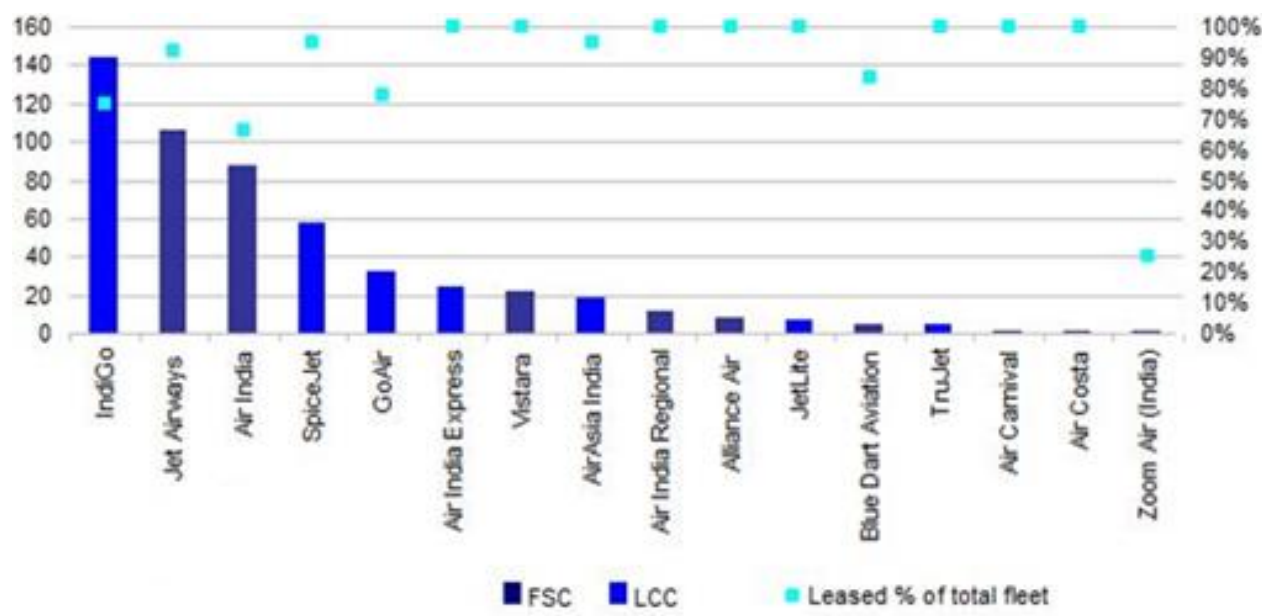

Figure 1. Proportion of Leased Aircrafts from Different Air Carriers Source: CAPA Database (2018)

\subsection{Market Share of Different Airlines}

In India, Low Cost Carriers ${ }^{9}$ (LCC) viz. Indigo, Spice Jet and Go Air, have more than 60 per cent shares in domestic operations compared to Full Service Airlines ${ }^{10}$ (FSA) viz. Air India, Jet Airways and Vistara.

Generally, tickets of LCC are priced lesser as compared to full-service airlines, however, the increasing competition within the industry has led to a significant reduction in gap in ticket prices in an endeavour to retain and increase the market share. The market share of different airlines until January 2019 is depicted in Figure 2. It is evident that Indigo leads the domestic industry with 42.5 per cent share followed by Spice Jet at $\mathbf{1 3 . 3}$ per cent. In fact, the market share of Indigo is more than the sum total of the market share of airlines in the next three positions.

It may be noted that Jet Airways has suspended its operations from April 2019 due to severe financial crunch ${ }^{11}$. Post grounding of Jet Airways, DGCA data of December $2019^{12}$ showed an increase in market shares of different airlines i.e. Indigo (47.1 per cent), Spice Jet (14.9 per cent), Air India (12.7 per cent), Go Air (10.6 per cent), Air Asia (6.2 per cent) and Vistara (5.2 per cent).

\footnotetext{
${ }^{9} \mathrm{~A}$ low-cost carrier is an airline that offers generally low fares in exchange for eliminating many traditional passenger services.

10 A full-service airline typically offers passengers in-flight entertainment, checked baggage, meals, beverages and comforts such as blankets and pillows in the ticket price.

11 https://economictimes.indiatimes.com/industry/transportation/airlines-/-aviation/jet-airways-staresat-shutdo wn-as-lenders-reject-appeal-for-funds-report/articleshow/68923128.cms, accessed on June 8 , 2019.

12 https://data.gov.in > catalog > monthly-air-traffic-statistics on January 27, 2020
} 


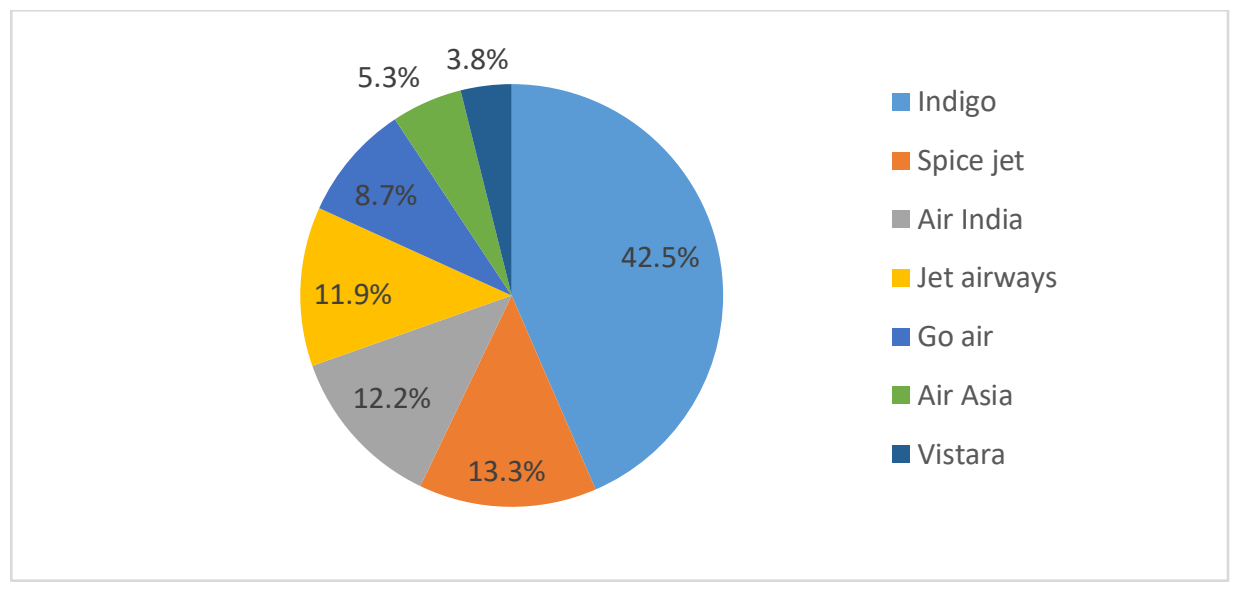

Figure 2. Market Share of Different Airline Companies Operating within India

Source: DGCA (accessed on January 31, 2020)

\section{Review of Literature}

The success of any bankruptcy prediction model lies in its ability to forecast as to which company would possibly become bankrupt that too few years before they file for bankruptcy. The initial attempt in this direction was made by Beaver (1966). He used cash flows for prediction using a univariate model. He identified six financial ratios as the ratios having discriminating power out of 29 ratios which he examined between 79 bankrupt and 79 non-bankrupt firms. These six ratios analysed profitability (net income plus depreciation and amortization/total liabilities, net income/total assets), long term solvency (total debt/total asset) and short-term liquidity (net working capital/total assets, current assets/ current liabilities, and cash, short-term investments, accounts receivable/operating expenses excluding depreciation and amortization). As per Beaver's analysis, the profitability ratio, net income plus depreciation and amortization/total liabilities best predicted the bankruptcy potential.

Altman (1968) developed the first bankruptcy model by using multiple ratios based on Multiple Discriminant Analysis (MDA) Model which more popularly is known as Z score model. It was generic in nature attempting to explain the potential bankruptcy amongst manufacturing companies that were publicly traded. The $Z$ score model was later replaced with ZETA model by Altman et al. (1977). Again, in 1993, the five variable model of Altman Z-Score model was revised to a four variable model popularly known as Altman Z" score model. The model is believed to be more effective for non-manufacturing firms. Hanson (2003) used this revised Altman Z" score model in his doctoral dissertation and this model gave fairly accurate results by classifying bankrupt service companies to the extent of 92 per cent accuracy within the first year, 69 per cent in second year and 54 per cent in third year 
Financial Distress in Indian Aviation Industry: Investigation Using Bankruptcy Prediction ...

respectively. Altman and Gritta (1984) used Altman ZETA model for assessing US aviation sector.

Studies on bankruptcy gained significant attention after the works of Beaver (1966) and Altman (1968). Various attempts were made from time to time by various authors to validate, to improve the existing models and to come up with new models. Ohlson (1980) used logistic regression for predicting bankruptcy. Zavgreen (1985) developed a logit model that could predict bankruptcy up to five years. Mixed logit method was used by Jones and Hensher (2004). Gepp and Kumar (2008) combined discriminant and logit analysis to create a bankruptcy prediction model.

Two discriminant analyses were conducted in 1980s specifically for aviation sector by Gritta (1982) and Altman and Gritta (1984). Over a while it was felt that industry specific models can probably give superior or more accurate results as compared to generic models. AIRSCORE model was developed by Chow et al. (1991) using airline data. Pilarski and Dinh (1999) developed a model known as P-Score for air transportation. Davalos, Gritta and Chow (1999) constructed a Neural Network Model for major US airlines and Gritta et al. (2000) constructed a neural network model for predicting financial distress in small carriers. Though these models predicted bankruptcy quite accurately for samples until one year but no major breakthrough was observed in their prediction capability over MDA or logistic regression (Gudmundsson, 2002).

The first study on the application of prediction models in the case of businesses in countries outside the United States was done by Altman and Gritta (1984). This study covered more than ten countries but included only one type of statistical model. Various studies have been carried out in the past to find out the best prediction model. But, most of the studies done were conducted on developed economies.

In the Indian context, most of the researches have focussed on applying Z score and modified $Z$ " score to select companies belonging to various sectors including aviation and other industries. Barki and Halageri, (2014) applied Altman Z score model on select companies in the Indian textile sector to analyse their financial strength. Panigrahi (2019), tried to assess the existence of financial distress in the Indian pharmaceutical sector by applying Altman Z Score Model to select companies belonging to this sector. Kumar and Anand (2013) used both Altman Z score and modified Z" score to assess the financial health of Kingfisher Airlines using data from 2005-06 to 2011-12. The results confirmed the poor financial health of the airline. Another study on selected companies in the Indian aviation sector using original and other variants of $Z$ score model also confirmed that Kingfisher airline was on the verge of bankruptcy (Vasantha et al., 2013). In another study calculating Altman Z score for bankruptcy prediction for the airline industry in India, it was concluded that the overall aviation sector in India is in financial distress excluding only Indigo which is in the safe zone (Kulkarni, 2018). 
While existing researches have used Z score model and modified Z Score Model in context of Indian Aviation Sector (Pandey \& Rathore, 2013; Safiuddin, 2017; Kulkarni, 2018;), none of the previous studies to the best of our understanding have considered Altman Modified Z Score, P-Score model, Fuzzy Logic and Krueze models all together for a combined analysis. The present study is an extension of previously carried researches in the aviation industry. The main purpose of this investigation is to assess the suitability of major bankruptcy prediction models by applying them to key airline companies in India. The objectives of this study are: (a) to analyse the financial situation of Indian airlines companies using various models (generic and industry specific); (b) to examine the existence of financial distress in the Indian airline industry; and, (c) to assess the applicability of different models in the Indian scenario.

\section{Research Methodology}

This study included four leading airlines of India viz. Indigo, Jet Airways, Air India and Spice Jet. Purposive sampling is used based on the market share and availability of data for the air carriers. The audited financial statements provided in the annual reports of these companies are the main source of financial data. The financial ratios which serve as input for various bankruptcy models are calculated from these statements. The data considered for this study is from 2015 to 2018. Only four years of data are considered as existing literature states that financial ratios can predict bankruptcy quite accurately within this time period (Kroeze, 2005).

In this paper four different models viz. Altman Z" Score Model, P-Score Model, Fuzzy Logic Model and Kroeze Model are used to study possibilities of the bankruptcy of Indian airlines companies using financial data. Of these four models, $Z$ " score is a generic model and the remaining three models are specifically designed using airline specific data. The selected models were chosen on the basis of extensive literature review and their predictive abilities as specified in the literature. Also, another criterion was that model should be non-proprietary so that intercept terms are publicly available. A brief about these four models are as follows:

\subsection{Altman Model (Z" Score)}

The original bankruptcy forecasting model of Altman popularly known as Z score has been successfully used by Gritta (1982) to predict the bankruptcies of both Braniff and Continental airlines, several years in advance before their actual filing of bankruptcies. The model is represented as:

$$
Z=0.012 X_{1}+0.014 X_{2}+0.033 X_{3}+0.006 X_{4}+0.999 X_{5}
$$

where, $X_{1}=$ liquidity ratio calculated as net working capital to total assets; $X_{2}=$ profitability ratio measured as retained earnings to total assets; $X_{3}=$ profitability ratio measured as operating profit to total assets; $X_{4}=$ leverage ratio measured as the market value of equity to book value of debt; $X_{5}=$ turnover ratio measured as 
Financial Distress in Indian Aviation Industry: Investigation Using Bankruptcy Prediction ...

operating revenues to total assets. Here, $X_{1}$ to $X_{5}$ are different ratios measuring different aspects of financial strength. This model was developed by Altman (1968) using multiple discriminant regression.

However, because of the increased use of operating lease in aviation sector, the reliability of this model has reduced over time (Gritta et al., 1995). There is a viewpoint that because of the significant use of operating lease, $X_{5}$ ratio can lead to distorted results (Gritta et al., 1995). Altman (1983) himself suggested the usage of a modified model the $Z$ " for service firms.

$$
Z^{\prime \prime}=6.56 X_{1}+3.26 X_{2}+6.72 X_{3}+1.05 X_{4}
$$

Where, $\mathrm{X}_{1}=$ net working capital/total assets; $\mathrm{X}_{2}=$ retained earnings/total assets; $\mathrm{X}_{3}$ = operating profit/total assets; and $X_{4}=$ book value of equity/book value of debt.

Based on the value of $Z^{\prime \prime}$, the companies are categorized into three groups (Table 2).

Table 2. Categorization of the Companies based on Z"Value

\begin{tabular}{cll}
\hline Z" value & \multicolumn{1}{c}{ Indicator } & \multicolumn{1}{c}{ Interpretation } \\
\hline$Z \leq 1.10$ & $\begin{array}{l}\text { High degree of Financial } \\
\text { Distress, Bankrupt }\end{array}$ & $\begin{array}{l}\text { Increased Probability of insolvency and } \\
\text { bankruptcy in the near future. }\end{array}$ \\
\hline $1.1 \leq Z \leq 2.60$ & Grey Zone & $\begin{array}{l}\text { Difficult to predict due to insufficient statistical } \\
\text { significance }\end{array}$ \\
\hline$Z \geq 2.60$ & $\begin{array}{l}\text { Low degree of Financial } \\
\text { Distress, Stable }\end{array}$ & $\begin{array}{l}\text { Increased Probability that insolvency and } \\
\text { bankruptcy will not happen in the near future. }\end{array}$ \\
\hline
\end{tabular}

The modified Z" model has been used in this paper because of significant use of lease in the Indian aviation sector. One of the limitations of Altman Z" score model is that it is generic in nature and not specifically designed for the aviation industry.

\subsection{The Pilarski or P-Score Model}

This is a logit model estimating the probability of bankruptcy developed by Pilarski and Dinh (1999). This model was primarily used for assessing the financial condition of major US air carriers and is believed to be giving superior results as compared to other models (Goodfriend et al., 2005). Popularly called as P-Score Model, this model gives $P$ value which is the Probability of Bankruptcy. Equation 3 and 4 shows twostep calculation of Probability of Bankruptcy P.

$$
W=-1.98 X_{1}-4.95 X_{2}-1.96 X_{3}-0.14 X_{4}-2.38 X_{5}
$$

where, $X_{1}=$ operating revenues/total assets; $X_{2}=$ retained earnings/total assets; $\mathrm{X}_{3}=$ equity/total debt obligations; $\mathrm{X}_{4}=$ liquid assets/current maturities of total debt obligations; $X_{5}=$ earnings before interest and taxes/operating revenues.

$$
P=1 /\left[1+e^{-w}\right]
$$

Here ' $\mathrm{e}$ ' is a mathematical constant and its value is equal to approximately 2.718 . 
Higher the P-value more is the probability of bankruptcy and vice-versa. Combining equation ( 3 ) and equation (4), it is clear that the P-Score is a measure of five different characteristics of the air carriers rather than just profitability. The P-Score model is considered to be appropriate for this study because it is specific to air carriers with a prediction rate of approx. 85.1 per cent. This model has also been used by the US Department of Transportation for tracking the financial strength of their air carriers (Gritta et al., 2006).

\subsection{Fuzzy Logic Model}

Another approach used by several researchers for predicting air carrier insolvency is fuzzy logic. Silva et al. (2005) applied a multivariate technique known as Hybrid Financial Statement Analysis (HFSAT) and tested the financial situation of a few American and Brazilian airlines. HFSAT is the combination of a discriminant analysis multi-variable model and the application of fuzzy logic to the firm's financial data. Following is the model used:

$$
Z=2.637-0.879 X_{1}+0.466 X_{2}-0.268 X_{3}-0.28 X_{4}
$$

Where, $\mathrm{X}_{1}=$ Shareholder Funds/Total Assets; $\mathrm{X}_{2}=$ (Current Liabilities + Long Term Liabilities)/Total Asset; $X_{3}=$ Net Operating Revenue/Total Assets; $X_{4}=$ Fixed Assets/Total Asset.

Based on $Z$ values, five groups have been identified:

$\begin{array}{lll}\text { - } & \text { Healthy: } & \mathrm{Z} \leq 1.862 \\ \text { - } & \text { Low Risk: } & 1.862 \leq \mathrm{Z} \leq 2.2 \\ \text { - } & \text { Moderate Risk: } & 2.2 \leq \mathrm{Z} \leq 2.515 \\ \text { - } & \text { High Risk: } & 2.515 \leq \mathrm{Z} \leq 2.73 \\ \text { - } & \text { Insolvent: } & \mathrm{Z} \geq 2.73\end{array}$

Chena, H. J. et al. (2009) also used fuzzy logic based models for prediction and have stated that prediction results based on this model are better as compared to classical models. Korol (2012) has stated that results of Fuzzy logic based models are superior as compared to Altman's Z score.

\subsection{Kroeze Model}

Kroeze (2005) used the following model for predicting airline bankruptcies:

$$
\mathrm{Y}_{\mathrm{a}}=0.268 \mathrm{X}_{1}+0.838 \mathrm{X}_{2}+0.111 \mathrm{X}_{3}+\dot{\varepsilon}
$$

Where, $\mathrm{Y}_{\mathrm{a}}=$ overall index; $\mathrm{X}_{1}=$ working capital/total assets; $\mathrm{X}_{2}=$ retained earnings/total assets; $X_{3}=$ book value of equity/total liabilities; $\dot{\varepsilon}=$ error term.

This model uses only three variables and applies Multiple Discriminant Analysis. Positive value of $Y_{a}$ indicates a non-bankruptcy and the negative value of $Y_{a}$ indicates a situation of bankruptcy. Variable $X_{2}$ defined as retained earnings/total assets is considered to be the most important predictor of bankruptcy as negative retained earnings are a sign of financial distress. Kroeze used this model to successfully 
Financial Distress in Indian Aviation Industry: Investigation Using Bankruptcy Prediction ...

predict the situation of Air Canada, US Airways and Hawaiian four years before their actual bankruptcies and that of Trans World Airlines (TWA) and American Trans Air (ATA), three and two years respectively before their actual filing of bankruptcies.

\section{Research Findings and Discussion}

This section is being divided into two parts for bankruptcy prediction and subsequent discussions. In the first part, all the four models discussed above have been analysed for four selected air carriers. The second part attempts to relate the results derived from the application of different models on select air carriers with the prevailing situation to assess the applicability of these models in Indian context.

\subsection{Altman Model (Z" Score)}

Table 3 shows the $Z$ " scores for four airlines from 2015 to 2018. It can be observed that except Indigo, all other airlines are showing a $Z$ " score less than 1.10. As discussed before, it indicates that these airlines i.e. Jet Airways, Air India and Spice Jet are under a high degree of financial stress. The $X$ variables are also showing negative values for most of the airlines which are resulting from negative profitability, negative net worth and negative equity ${ }^{13}$.

Table 3. Z" Score of Air Carriers

\begin{tabular}{|c|c|c|c|c|c|c|}
\hline Carrier & Year & $X_{1}$ & $\mathrm{X}_{2}$ & $X_{3}$ & $X_{4}$ & Z" Score \\
\hline \multirow{4}{*}{ Indigo } & 2015 & $(0.135)$ & 0.225 & 0.153 & 0.117 & 0.999 \\
\hline & 2016 & (0.003) & 0.180 & 0.225 & 0.906 & 3.032 \\
\hline & 2017 & (0.118) & 0.183 & 0.147 & 1.578 & 2.464 \\
\hline & 2018 & $(0.111)$ & 0.194 & 0.171 & 3.158 & 4.368 \\
\hline \multirow{4}{*}{ Jet Airways } & 2015 & $(0.213)$ & $(0.572)$ & $(0.049)$ & $(1.207)$ & $(4.856)$ \\
\hline & 2016 & $(0.215)$ & (0.5096) & 0.069 & $(1.062)$ & (3.720) \\
\hline & 2017 & (0.569) & (0.945) & 0.079 & (0.897) & (7.222) \\
\hline & 2018 & $(0.566)$ & $(0.970)$ & $(0.0538)$ & (1.368) & (8.675) \\
\hline \multirow{4}{*}{ Air India } & 2015 & $(0.588)$ & $(0.151)$ & $(0.068)$ & $(0.556)$ & (5.391) \\
\hline & 2016 & $(0.433)$ & (0.105) & 0.002 & (0.533) & (3.733) \\
\hline & 2017 & (0.686) & (0.160) & 0.008 & (0.560) & (5.556) \\
\hline & 2018 & $(0.177)$ & $(0.165)$ & (0.051) & (0.759) & (9.396) \\
\hline \multirow{4}{*}{ Spice Jet } & 2015 & (0.598) & $(1.231)$ & $(0.232)$ & (0.891) & (10.433) \\
\hline & 2016 & (0.584) & $(0.923)$ & 0.172 & $(1.013)$ & (6.746) \\
\hline & 2017 & (0.470) & (0.772) & 0.149 & (0.592) & (5.222) \\
\hline & 2018 & $(0.183)$ & $(0.409)$ & 0.151 & $(0.0426)$ & $(1.562)$ \\
\hline
\end{tabular}

Note: Figures in parentheses implies negative numbers

The values of equity/debt ratio $\left(\mathrm{X}_{4}\right)$ are worth mentioning in this aspect. This ratio shows the relative proportion of debt and equity in the total capital structure. Higher is the proportion of debt, riskier is the firm. Except for Indigo, almost all the companies are showing negative equity/debt ratio and this is because of the

\footnotetext{
${ }^{13}$ Negative equity is a situation where liabilities exceed assets.
} 
negative equity. This negative equity is due to the accumulated losses over the years and then excessive debt to cover these losses. On the contrary, in the case of Indigo, the $Z$ " score has been positive in all four years, although with varying degrees. This indicates that Indigo is clearly in a low degree of financial stress.

\subsection{The Pilarski or P-Score Model}

As already stated, $\mathrm{P}$ is the probability of going bankrupt. Hence, greater the $\mathrm{P}$-value, the higher is the financial distress and more is the probability bankrupt.

It is clearly evident from Table 4 that except Indigo and Spice Jet, the other two airlines viz. Jet Airways and Air India are showing more than 50 per cent probability of going bankrupt. Indigo is evidently out of danger zone with almost nil probability of going for bankruptcy. The probability of Spice Jet becoming bankrupt has also gone down significantly from approximately 20 per cent in 2015 to 2 per cent in 2018. The P-Scores are giving a warning signal in case of Jet Airways and Air India. In case of Jet Airways, the probability of becoming financially bankrupt was significantly very high since 2015 reaching up to 98 per cent in 2018.

Table 4. P Score of Air Carriers

\begin{tabular}{lccccccccc}
\hline Carriers & Year & $\mathbf{X}_{\mathbf{1}}$ & $\mathbf{X}_{\mathbf{2}}$ & $\mathbf{X}_{\mathbf{3}}$ & $\mathbf{X}_{\mathbf{4}}$ & $\mathbf{X}_{\mathbf{5}}$ & $\mathbf{W}$ & $\mathbf{P}$ & $\mathbf{\%}$ \\
\hline \multirow{4}{*}{ Indigo } & 2015 & 1.658 & 0.225 & 0.117 & 0.795 & 0.141 & $(4.48)$ & 0.011 & 1.120 \\
& 2016 & 1.391 & 0.180 & 0.906 & 0.995 & 0.194 & $(6.02)$ & 0.002 & 0.2418 \\
& 2017 & 1.620 & 0.183 & 1.577 & 0.850 & 0.133 & $(7.641)$ & 0.00048 & 0.048 \\
& 2018 & 1.560 & 0.194 & 3.157 & 0.861 & 0.151 & $(10.710)$ & 0.000022 & 0.002 \\
\hline \multirow{4}{*}{ Jet } & 2015 & 0.624 & $(0.572)$ & $(1.207)$ & 0.702 & $(0.015)$ & 3.899 & 0.980 & 98.01 \\
& 2016 & 0.789 & $(0.510)$ & $(1.063)$ & 0.707 & 0.141 & 2.608 & 0.931 & 93.14 \\
& 2017 & 1.507 & $(0.945)$ & $(0.897)$ & 0.488 & 0.145 & 3.036 & 0.954 & 95.42 \\
Air India & 2018 & 1.677 & $(0.970)$ & $(1.368)$ & 0.566 & 0.004 & 4.074 & 0.983 & 98.32 \\
\hline \multirow{5}{*}{ Spice Jet } & 2015 & 0.511 & $(0.151)$ & $(0.556)$ & 0.189 & $(0.092)$ & 1.018 & 0.735 & 73.47 \\
& 2016 & 0.567 & $(0.105)$ & $(0.533)$ & 0.415 & 0.017 & 0.343 & 0.585 & 58.48 \\
& 2017 & 0.608 & $(0.160)$ & $(0.560)$ & 0.206 & 0.159 & 0.280 & 0.570 & 56.95 \\
& 2018 & 0.709 & $(0.165)$ & $(0.759)$ & 0.134 & $(0.033)$ & 0.960 & 0.723 & 72.30 \\
\hline & 2015 & 1.996 & $(0.123)$ & $(0.891)$ & 0.364 & $(0.116)$ & $(1.369)$ & 0.203 & 20.280 \\
& 2017 & 2.787 & $(0.092)$ & $(1.012)$ & 0.419 & 0.096 & $(1.385)$ & 0.200 & 20.027 \\
& 2018 & 1.938 & $(0.077)$ & $(0.592)$ & 0.479 & 0.069 & $(2.987)$ & 0.048 & 4.8031 \\
& & $(0.043)$ & 0.768 & 0.078 & $(3.845)$ & 0.021 & 2.090 \\
\hline
\end{tabular}

Source: Calculated from Annual Reports of different Airline companies.

Note: Figures in parentheses implies negative numbers

This is a very significant observation as this particular carrier has been grounded since mid-April 2019 because of financial issues. Government sponsored Air India is also showing more than 70 per cent probability of becoming bankrupt. This airline is surviving only due to financial assistance from the government. 
Financial Distress in Indian Aviation Industry: Investigation Using Bankruptcy Prediction ...

\subsection{Fuzzy Logic Model}

From the Fuzzy Logic Z Scores portrayed in Table 5, it is noticeable that none of the airlines are in a healthy zone with $Z<1.82$. Jet Airways and Air India are in the zone of severe financial distress as good as being insolvent with Z score greater than 2.73 for all the four years since 2015. Very high total debt coupled with negative values of retained earnings and equity is responsible for this plight of both these air carriers. Indigo is the only airline that has gradually moved into a low risk category as per the classification pattern of this model. This is because of the increase in its $X_{1}$ ratio over the period of study. Spice Jet is another airline that has moved into medium risk category shown by consistent improvement in its $Z$ score. However, the negative value of equity and retained earnings remain a significant cause of concern for Spice Jet.

\section{Table 5. Fuzzy Logic Z Scores}

\begin{tabular}{lcccccc}
\hline Carrier & Year & $\mathbf{X}_{\mathbf{1}}$ & $\mathbf{X}_{\mathbf{2}}$ & $\mathbf{X}_{\mathbf{3}}$ & $\mathbf{X}_{\mathbf{4}}$ & $\mathbf{Z}^{\text {" Score }}$ \\
\hline \multirow{4}{*}{ Indigo } & 2015 & 0.041 & 1.009 & 1.358 & 0.476 & 2.574 \\
& 2016 & 0.235 & 0.853 & 1.391 & 0.409 & 2.341 \\
& 2017 & 0.330 & 0.996 & 1.620 & 0.331 & 2.285 \\
Jet Airways & 2018 & 0.480 & 0.952 & 1.560 & 0.310 & 2.154 \\
& 2015 & $(0.230)$ & 1.287 & 1.099 & 0.500 & 3.004 \\
& 2016 & $(0.171)$ & 1.257 & 1.200 & 0.481 & 2.917 \\
Air India & 2017 & $(0.605)$ & 1.786 & 2.013 & 0.458 & 3.333 \\
& 2018 & $(0.653)$ & 0.608 & 2.101 & 0.263 & 2.858 \\
\hline \multirow{4}{*}{ Spice Jet } & 2015 & $(0.522)$ & 1.663 & 0.511 & 0.863 & 3.492 \\
& 2016 & $(0.480)$ & 1.641 & 0.567 & 0.692 & 3.478 \\
& 2017 & $(0.558$ & 1.831 & 0.608 & 0.822 & 3.587 \\
& 2018 & $(0.767)$ & 2.370 & 0.709 & 0.817 & 3.997 \\
\hline
\end{tabular}

Source: Calculated from Annual Reports of different Airline companies.

Note: Figures in parentheses implies negative numbers

\subsection{Kroeze Model}

Table 6 portrays the $Y_{a}$ score of various air carriers. It shows that except for Indigo, $Y_{a}$ scores of all other airlines is negative which implies a situation of probable bankruptcy. The retained earnings/total assets (variable $X_{2}$ ) is negative for all the airlines except Indigo. As $X_{2}$ considers retained earnings, it is quite obvious that no company can survive for long with a negative value of retained earnings. However, Spice Jet is showing an improvement in performance over a period of time with its $\mathrm{Y}_{\mathrm{a}}$ score improving despite being in distress zone. For Air India and Jet Airways, the $\mathrm{Y}_{\mathrm{a}}$ score is continuously deteriorating. 
Table 6. Kroeze Model $\mathrm{Y}_{\mathrm{a}}$ Scores

\begin{tabular}{cccccc}
\hline carrier & year & $\mathrm{x}_{1}$ & $\mathrm{x}_{2}$ & $\mathrm{x}_{3}$ & ya score \\
\hline \multirow{4}{*}{ Indigo } & 2015 & $(0.135)$ & 0.225 & 0.117 & 0.166 \\
& 2016 & $(0.003)$ & 0.180 & 0.906 & 0.251 \\
& 2017 & $(0.118)$ & 0.183 & 1.577 & 0.297 \\
& 2018 & $(0.111)$ & 0.194 & 3.158 & 0.483 \\
\hline \multirow{4}{*}{ Jet Airways } & 2015 & $(0.212)$ & $(0.572)$ & $(1.207)$ & $(0.670)$ \\
& 2016 & $(0.215)$ & $(0.510)$ & $(1.063)$ & $(0.603)$ \\
& 2017 & $(0.569)$ & $(0.945)$ & $(0.897)$ & $(1.044)$ \\
& 2018 & $(0.566)$ & $(0.970)$ & $(1.368)$ & $(1.117)$ \\
\hline \multirow{4}{*}{ Air India } & 2015 & $(0.588)$ & $(0.151)$ & $(0.556)$ & $(0.346)$ \\
& 2016 & $(0.433)$ & $(0.105)$ & $(0.533)$ & $(0.263)$ \\
& 2017 & $(0.686)$ & $(0.160)$ & $(0.560)$ & $(0.380)$ \\
& 2018 & $(1.177)$ & $(0.165)$ & $(0.759)$ & $(0.538)$ \\
\hline \multirow{5}{*}{ Spice Jet } & 2015 & $(0.598)$ & $(1.231)$ & $(0.891)$ & $(1.291)$ \\
& 2016 & $(0.583)$ & $(0.923)$ & $(1.013)$ & $(1.042)$ \\
& 2017 & $(0.470)$ & $(0.772)$ & $(0.592)$ & $(0.839)$ \\
& 2018 & $(0.182)$ & $(0.409)$ & $(0.043)$ & $(0.396)$ \\
\hline
\end{tabular}

Source: Calculated from Annual Reports of different Airline companies.

Note: Figures in parentheses implies negative numbers

\subsection{Comparison of All Four Models}

Table 7 shows the consolidated result of all the four models used in this paper. Indigo is found to be the only stable and consistent air carrier in the Indian aviation industry among the four major airlines. The data presented in the balance sheet also confirms the same. The Operating Revenue of Indigo has improved consistently from INR 13,925.3 crore $^{14}$ in March 2015 to INR 23,020.9 crore in March 2018. The company remained profitable continuously on year to year basis with a profit of INR 1,304.2 crore in March 2015 to INR 2,242.4 crore in March $2018^{15}$.

Spice Jet has shown continuous improvement in its financial performance over the period of the study. Operating Revenue of Spice Jet has improved from INR 5,201.53 crore in March 2015 to INR 7,795.09 crore in March 2018. The company became profitable with a profit of INR 566.65 crore in March 2018 from a loss of INR 687.05 crore in March $2015^{16}$. It has revived splendidly over the last few years from almost a near-death like situation in 2014, when the airline was almost about to shut down its operations due to severe cash crunch $^{17}$. The probable reasons for this positive development may be tightening of cost and expansion to new routes which

\footnotetext{
${ }^{14}$ INR is the Indian Rupee and the currency of India. As on May 11, 2020, 1 \$US = 75.53 INR. Similarly, crore is in the Indian numbering system. One crore denotes ten million.

${ }^{15}$ Annual Report of Indigo FY 2014-15, 2017-18 on June 7, 2019.

${ }^{16}$ Annual Report of Spice Jet FY 2014-15, 2017-18 on June 7, 2019.

17 https://www.livemint.com/Companies/T2BOBSwziSYSnEDPMJ2xEM/The-SpiceJet-turnaround-storyand-how-it-became-worlds-best.html, accessed on June 9, 2019.
} 
Financial Distress in Indian Aviation Industry: Investigation Using Bankruptcy Prediction ...

generated better revenues. However, Spice Jet is yet to be considered out of danger as per the scores of various models in Table 7.

The operations of Jet Airways are being suspended since the middle of April 2019 due to mounting financial burdens and this poor situation of Jet airways is illustrated appropriately by all the models used in this paper. This company is struggling with a debt of approx. INR $11,261 \mathrm{crore}^{18}$. The airline has not been able to pay to any of the stakeholders including, banks, creditors, vendors, lessors and most regrettably, salary to its employees. Its aggressive debt-based expansion plans have mounted its debt level significantly from less than INR 3,000 crore in 2005 to approximately INR 16,600 crore in March 2009. Despite levelling to a great extent, the overall debt level continued to be on a higher side at around INR 7,600 crore in March 2018. Similarly, its net worth turned red first in March 2012, with a negative value of INR 10 crore and it has consistently worsened since then. Hence, with a negative net worth and significantly higher debt levels, the airline leverage ratio has been very unfavourable over the years. The financial statements of Jet Airways also show a continuous loss from 2008 onwards with an exception of marginal profits in 2016 and $2017^{19}$.

Table 7. Consolidated Scores of Various Models for Selected Airlines

\begin{tabular}{|c|c|c|c|c|c|}
\hline Carrier & Year & Z" Score & P Score & Fuzzy Logic & $\mathbf{Y}_{\mathrm{a}}$ Score \\
\hline \multirow{4}{*}{ Indigo } & 2015 & 0.999 & 0.01119 & 2.574 & 0.166 \\
\hline & 2016 & 3.032 & 0.00241 & 2.341 & 0.251 \\
\hline & 2017 & 2.464 & 0.00048 & 2.285 & 0.297 \\
\hline & 2018 & 4.368 & 0.00002 & 2.154 & 0.483 \\
\hline \multirow{4}{*}{ Jet Airways } & 2015 & $(4.856)$ & 0.980 & 3.004 & $(0.670)$ \\
\hline & 2016 & (3.720) & 0.931 & 2.917 & (0.603) \\
\hline & 2017 & (7.222) & 0.954 & 3.333 & (1.043) \\
\hline & 2018 & (8.675) & 0.983 & 2.858 & (1.117) \\
\hline \multirow{4}{*}{ Air India } & 2015 & (5.391) & 0.735 & 3.492 & $(0.347)$ \\
\hline & 2016 & (3.733) & 0.585 & 3.478 & (0.263) \\
\hline & 2017 & (5.555) & 0.570 & 3.587 & $(0.380)$ \\
\hline & 2018 & (9.396) & 0.723 & 3.997 & (0.538) \\
\hline \multirow{4}{*}{ Spice Jet } & 2015 & $(10.571)$ & 0.203 & 3.037 & (1.291) \\
\hline & 2016 & (6.631) & 0.200 & 2.955 & (1.042) \\
\hline & 2017 & $4.943)$ & 0.048 & 2.672 & (0.839) \\
\hline & 2018 & (1.703) & 0.021 & 2.498 & (0.396) \\
\hline
\end{tabular}

Note: Figures in parentheses implies negative numbers

All four models also portray the adverse financial situation of Air India. With a laidback attitude and poor operational efficiency, this particular airline is surviving only because of government packages. It is virtually in a bankrupt position for all practical purposes. After pumping in INR 28,000 crore by the Indian government for its

\footnotetext{
${ }^{18} \mathrm{https}$ ://www.thehindubusinessline.com/economy/logistics/jets-gross-debt-likely-to-add-up-to-11261cr/article 26905023.ece, accessed on May 10, 2019.

${ }^{19}$ Various Annual Reports of Jet Airways on June 7, 2019.
} 
turnaround in 2014, this airline could barely generate an operating profit of INR 403.03 crore in two financial years (2015-16 and 2016-17) ${ }^{20}$.

To sum up, the result of all the models depicts a relatively healthy low risk situation for Indigo and gradually improving condition for Spice Jet. In case of Jet Airways and Air India, all the models captured their severely bad financial position over the period of study.

\section{Concluding Remarks}

The primary objective of this paper was to analyse the financial situation of four major Indian airline companies. Except for Indigo, all the other chosen airlines (viz. Spice Jet, Jet Airways and Air India) have been under financial distress as specified by all the four chosen models i.e. Altman Z" Score, P-Score, Fuzzy Logic and Kroeze Model. For Indigo, Altman Z" Score, P-Score and Kroeze Model have shown healthy stable financial position. Fuzzy logic has put Indigo also in medium to low risk category based on its financial situation.

The models have highlighted the existence of severe financial distress in the Indian aviation sector. The results are in line with the previous studies conducted (Tyagi and Dutta, 2017; Kulkarni, 2018) which have also indicated the existence of financial distress in the overall aviation sector in India. The study also aimed to assess the suitability of different models in the Indian context. These models despite drawing data from financial statements for calculating various ratios give different weightage to various ratios and employ different statistical techniques.

The scores from various models have been good indicators and successfully captured the prevailing financial conditions of different air carriers in India. All the four models have depicted the existence of extreme financial stress for Jet Airways leading to a very high probability of bankruptcy well in advance right from the year 2015. Jet Airways operations are suspended since April 2019. From the study it can be safely concluded that all of these models can be applied in Indian Aviation Sector for predicting the possibility of bankruptcy.

However, it should be noted that the existence of financial distress does not always lead to a situation of bankruptcy. It only indicates a likelihood of future failure which can also be reversed by taking appropriate corrective measures and strategies either by the company itself or by the government. This particular analysis of the Indian airline companies is also limited to the extent of availability of accurate financial data. The result of this study shows the potential for further research in this sector. Further studies can focus on identifying various variables leading to the financial distress and in identifying variables critical in improving the financial performance of airlines on a case to case basis. This kind of analysis for any industry can be useful for different stakeholders like stockholders, bankers, customers, lessors, and other

\footnotetext{
${ }^{20}$ https://www.businesstoday.in/current/economy-politics/a-loss-making-airline-for-almost-a-decadeair-india-has-no-reason-to-exist/story/281813.html, accessed on June 5, 2019.
} 
Financial Distress in Indian Aviation Industry: Investigation Using Bankruptcy Prediction ...

creditors, among others. The management of different companies and the government can also take appropriate policy measures well in advance to improve the financial performance on a case to case basis.

\section{References}

Altman, E. (1968). Financial ratios, Discriminant Analysis and the Prediction of Corporate Bankruptcy. Journal of Finance, 23(23), 589-609. https://doi.org/10.1111/j.15406261.1968.tb00843.x

Altman, E., Haldeman, R. \& Narayanan (1977). ZETA Analysis: A New Model for Bankruptcy Classification. Journal of Banking and Finance, XXVI(3), 24-56.

Altman, E. (1983). Corporate Financial Distress: A Complete Guide to Predicting, Avoiding and Dealing with Bankruptcy. New York. John Wiley \& Sons.

Altman, E. \& Gritta, R. (1984). Airline Bankruptcy Propensities: A ZETA Analysis. Journal of the Transportation Research Forum, 25(1), 150-154.

Altman, E. (1984). The Success of Business Failure Prediction Models. Journal of Banking and Finance, 8, 171-198. https://doi.org/10.1016/0378-4266(84)90003-7

Barki, G. \& Halageri, S. (2014). Analysis of Financial Strength of Select Firms from Indian Textiles Industry using Altman's ' $Z$ ' Score Analysis. Acme Intellects International Journal of Research in Management, Social Sciences \& Technology, 5(5).

Beaver, W. (1966). Financial Ratios as Predictors of Failure. Journal of Accounting Research, IV, 71-111. https://doi.org/10.2307/2490171

Chen, H.J., Huang, S.Y. and Lin, C.S. (2009). Alternative Diagnosis of Corporate Bankruptcy: A Neuro Fuzzy Approach. Expert Systems with Applications, 36(4), 7710-7720. https://doi.org/10.1016/i.eswa.2008.09.023

Chow, G., Gritta, R. \& Leung, E. (1991). A New Approach to Forecasting Financial Distress in Air Transportation: The AIRSCORE Model. Journal of the Transportation Research Forum, XXXI (2), 371-376.

Davalos, S., Gritta, R. \& Chow, G. (1999). The Application of Neural Network Approach to Predicting Bankruptcy Risks facing the Major US Carriers: 1979-1996. Journal of Air Transport Management, 5(2), 81-86. https://doi.org/10.1016/S0969-6997(98)00042-8

Fung, M. K. Y., Law, J. S., \& Ng, L. W. K. (2006). Economic contribution to Hong Kong of the aviation sector: A value-added approach. Chinese Economy, 39(6), 19-38. https://doi.org/10.2753/CES1097-1475390602

Gepp, A. \& Kumar, K. (2008). The Role of Survival Analysis in Financial Distress Prediction. International Research Journal of Finance and Economics, 16, 14-34.

Gritta, R. D. (1982). Bankruptcy Risks Facing the Major U.S. Airlines. Journal of Air Law \& Commerce, 40(7), 89-108.

Gritta, R. D., Chow, G. \& Lippman, E. (1995). The Impact of the Capitalization of Leases on Financial Analysis: An Issue Revisited. Logistics and Transportation Review. 30 (2), 189-202.

Gritta, R. D., Wang, M., Davalos, S. \& Chow, G. (2000). Forecasting small air carrier bankruptcies using a Neural Network Approach. Journal of Financial Management and Analysis, 13(1), 44-49.

Gritta, R. D., Adrangi, B., Davalos, S. \& Bright, D. (2006). A Review of the History of Air Carrier Bankruptcy Forecasting and the Application of Various Models to the U.S. Airline Industry: 
Samik SHOME \& Sushma VERMA

1980-2005. XIV International Economic History Congress, Helsinki. https://doi.org/10.2469/faj.v30.n2.47

Goodfriend, J., Gritta, R., Adrangi, B. \& Davalos, S. (2004). Assessing the Financial Condition of the Major U.S. Passenger Airlines Over the 1993-2003 Period Using the P Score and Z" Score Discriminant Models. Credit and Financial Management Review, 10(4).

Gudmundsson, S. V. (2002). Airline Distress Prediction Using Non-Financial Indicators. Journal of Air Transportation, 7(2), 3-24.

Hanson, R. O. (2003). A Study of Altman's Revised Four-variable Z \& Prime Score Bankruptcy Prediction Model as it applies to the Service Industry. UMI ProQuest Digital Dissertations. Doctoral Dissertation. Nova Southeastern University, 2003, Ft. Lauderdale, Florida.

Jayaraman, A. R. \& Srinivasan, M. R. (2014). Performance evaluation of banks in India: A Shannon-DEA approach. Eurasian Journal of Business and Economics, 7, 51-68.

Jones, S. \& Hensher, D. A. (2004). Predicting Firm Financial Distress: A Mixed Logit Model. The Accounting Review, 79(4), 1011-1038. https://doi.org/10.2308/accr.2004.79.4.1011

Korol, T. (2012). Fuzzy Logic in Financial Management. In P. E. Dadios, Fuzzy Logic - Emerging Technologies and Applications, 259-286. Poland. https://doi.org/10.5772/35574

Kroeze, C. (2005). Predicting Airline Corporate Bankruptcies using a Modified Altman Z -Score Model. UNLV Retrospective Theses \& Dissertations. 2609.

https://digitalscholarship.unlv.edu/rtds/2609.

Kumar, M. \& Anand, M. (2013). Assessing Financial Health of a Firm Using Altman's Original and Revised Z-Score Models: a Case of Kingfisher Airlines Ltd (India). Journal of Applied Management and Investment, 2(1), 36-48.

Kulkarni, S. (2018). Analysis of Z score for BSE Listed Airline Companies in India, Paridnya - The MIBM Research Journal, 6(1), Online ISSN No. 2457-0281.

Lukic, R. (2014). Analysis of the efficiency of small independent retailers in Serbia. Eurasian Journal of Business and Economics, 7(13), 91-103.

Ohlson, J. A. (1980). Financial Ratios and the Probabilistic Prediction of Bankruptcy. Journal of Accounting Research, 18(1), 109-131. https://doi.org/10.2307/2490395

Pandey, S.L.D. \& Rathore, G.S. (2013). An Analysis of Bankruptcy in Indian Aviation Infrastructure Firms. The Indian Journal of Commerce, Vol. 66 No. 3, pp. 238-252.

Panigrahi, A. (2019). Validity of Altman's "Z" Score Model in Predicting Financial Distress of Pharmaceutical Companies. NMIMS Journal of Economics and Public Policy 4(1).

Pilarski, A., \& Dinh, T. (1999). Numerical Scoring Approach to Credit Risk Analysis. Handbook of Airline Finance, 329-342. New York: McGraw-Hill.

Safiuddin, S.K. (2017). Prediction of Insolvency-A Study of Select Companies in Indian Aviation Industry. International Research Journal of Management Science \& Technology, Vol. 8 No. 10, pp. 304-309.

Silva, V., Respico A. Spiritu Santo, S. and L. da Silva Portugal (2005). Using the "Hybrid Financial Statement Analysis Technique" to Rate and Monitor Airlines Financial Status. Proceedings of the Air Transportation Research Society, World Conference on Transport Research. Paper presented in Rio de Janeiro.

Tyagi, V. \& Datta, M. (2017). Bankruptcy Potential of Indian Aviation Industry: An Analysis of Selected Firms. Research Bulletin, 42(4), 38-49. https://doi.org/10.17015/ejbe.2016.017.01 
Financial Distress in Indian Aviation Industry: Investigation Using Bankruptcy Prediction ...

Tyagi,S. \& Nauriyal, D. K. (2016). Profitability determinants in Indian drugs and pharmaceutical industry: An analysis of pre and post TRIPS period. Eurasian Journal of Business and Economics, 9(17), 1-21.

Vasantha, S., Dhanraj, V. \& Thiayalnayaki. (2013). Prediction of Business Bankruptcy For Selected Indian Airline Companies Using Altman's Model. International Journal of Research in Business Management, 1(4), 19-26.

Zavgren, C. V. (1985). Assessing the Vulnerability to Failure of American Industrial Firms: A Logistic Analysis. Journal of Business Finance \& Accounting, 12(1), 19-45. https://doi.org/10.1111/j.1468-5957.1985.tb00077.x 